J. Clin. Chem. Clin. Biochem.

Vol. 18, 1980, pp. 579-583

\title{
4-Methoxy-3-hydroxyphenylglycol as an Internal Standard for the Determination of 3-Methoxy-4-hydroxyphenylglycol in Urine: \\ Results Obtained in Depressed Patients and Healthy Controls
}

\author{
By H. J. Gaertner, Gerlinde Wiatr
}

Universitäts-Nervenklinik (Direktor: Prof. Dr. H. Heimann) Tübingen and

H.J. Kuss

Nervenklinik (Direktor: Prof. Dr. H. Hippius) der Universität München

(Received December 14, 1979/March 20, 1980)

Summary: A modification of the method developed by Dekirmenjian \& Maas ((1970) Anal. Biochem. 35, 113-122) is described for the determination of 3-methoxy-4-hydroxyphenylglycol in urine. The use of 4-methoxy-3-hydroxyphenylglycol as an internal standard improves the accuracy, simplicity and reproducibility. Therefore, the method is suitable for routine determination in laboratories without gas chromatography/mass spectrometry equipment. Some results obtained in depressed patients and healthy controls are presented.

4-Methoxy-3-hydroxyphenylglykol als interner Standard für die Bestimmung von 3-Methoxy-4-hydroxyphenylglykol im Harn:

Ergebnisse bei Patienten mit Depression und gesunden Kontrollpersonen

Zusammenfassung: Zur Bestimmung von 3-Methoxy-4-hydroxyphenylglykol im Harn wird eine Modifikation der Methode von Dekirmenijan \& Maas ((1970) Anal. Biochem. 35, 113-122) beschrieben. Die Verwendung von 4-Methoxy-3-hydroxyphenylglykol als internem Standard verbessert Richtigkeit, Handhabung und Reproduzierbarkeit. Daher ist die Methode für Routinebestimmungen in Laboratorien ohne Gaschromatographie/Massenspektrometrie-Ausrüstung geeignet. Einige Ergebnisse von Patienten mit Depression und gesunden Kontrollen werden mitgeteilt.

\section{Introduction}

The major metabolites of norepinephrine in urine are 3-methoxy-4-hydroxymandelic acid and 3-methoxy-4hydroxyphenylglycol. It is assumed that the aldehydes produced in the metabolism of norepinephrine follow a predominantly reductive pathway to the glycol in the central nervous system (2). The average contribution by brain to the total body production of 3-methoxy4-hydroxyphenylglycol is estimated to be $63 \%$ in man (3).

The value of 3-methoxy-4-hydroxyphenylglycol determinations for the elucidation of the aetiology of depressive illness is doubtful, but they may be useful for classifying depressive disorders and predicting drug response $(4,5)$.

\section{Materials and Methods}

Chemicals and solutions

$1.0 \mathrm{~mol} / \mathrm{l}$ Acetate buffer $\mathrm{pH} 6.0$

$20 \mathrm{~g} / 1$ EDTA

$\mathrm{Na}_{2} \dot{\mathrm{S}}_{2} \mathrm{O}_{5}$ p. A.

$1.0 \mathrm{~mol} / 1 \mathrm{KHCO}$

$\mathrm{NaCl}$ p. A.

Chloroform p. A.

Ethyl acetate p. A. freshly distilled over $\mathrm{K}_{2} \mathrm{CO}_{3}$

Pyridine p. A.

Toluene p. A. (all Merck, Darmstadt)

$\beta$-Glucuronidase/Arylsulfatase, EC 3.2.1.31/3.1.6.1 (Boehringer, Mannheim)

Pentafluoropropionic anhydride (Pierce, Rotterdam)

3-Methoxy-4-hydroxyphenylglycol piperazine salt (EGA-Chemie, Steinheim)

4-Methoxy-3-hydroxyphenylglycol (R. Paesel KG, Frankfurt)

Dimethyldichlorosilane (Fluka, Neu-Ulm) 
Equipment

Gas chromatograph: Hewlett-Packard 57 30A (ECD, constant current and variable pulser frequency)

Automatic sampler: Hewlett-Packard 76 71A

Integrator:

Hewlett-Packard 33 80A

\section{Treatment of glassware}

$4 \mathrm{ml}$ glass-stoppered tubes for derivatisation should be silanized with a solution of $50 \mathrm{~g} / \mathrm{l}$ dimethyldichlorosilane in toluene and then dried overnight at $300^{\circ} \mathrm{C}$. Silanisation should be repeated every month.

\section{Procedure}

\section{Urine sampling}

Two or three 24-h urine samples were collected from untreated in-patients or healthy volunteers. Patients had to meet the criteria for primary affective disorders as described by Feighner et al. (6). The criterion for bipolarity was a prior history of hypomania or mania. After determination of $\mathrm{pH}$ and creatinine (according to the method of Jaffe) $0.5 \mathrm{~g} / 1$ sodium disulfite was added and aliquots were stored at $-20^{\circ} \mathrm{C}$.

\section{Incubation}

Since more than $90 \%$ of urinary 3-methoxy-4-hydroxyphenylglycol is present in the form of the glucuronide and the sulphate (10), extraction had to be preceded by enzymic hydrolysis.

$0.2 \mathrm{ml} 1.0 \mathrm{~mol} / 1$ acetate buffer, $0.1 \mathrm{ml} 20 \mathrm{~g} / 1$ EDTA and $0.2 \mathrm{ml}$ $\beta$-glucuronidase arylsulfatase were added to $0.5 \mathrm{ml}$ urine and incubated at $37^{\circ} \mathrm{C}$ for $24 \mathrm{~h} .0 .1 \mathrm{ml}$ of a solution of $0.02 \mathrm{~g} / 1$ 4-methoxy-3-hydroxyphenylglycol in acetate buffer $\mathrm{pH} 6.0$ were added to the hydrolyzed mixture.

In experiments according to procedure a) (described below), increasing amounts of a solution of $0.01 \mathrm{~g} / 1$ 3-methoxy-4hydroxyphenylglycol (free acid) in acetate buffer $\mathrm{pH} 6.0$ were also added.

\section{Extraction}

The mixture was extracted twice with $2 \mathrm{ml} \mathrm{CHCl}_{3}$ and the organic layer discarded. After addition of $200 \mathrm{mg} \mathrm{NaCl}$, the aqueous phase was extracted with $2 \mathrm{ml}$ ethyl acetate, while shaking during one minute on a Vortex mixer. After centrifugation, the organic phase was carefully removed with a Pasteur pipette. The extraction was repeated three times. The combined organic layers were brought to $2 \mathrm{ml}$ at reduced pressure with a rotary evaporator and then washed with $1 \mathrm{ml} 1 \mathrm{~mol} / 1 \mathrm{KHCO}_{3}$. The $\mathrm{KHCO}_{3}$ layer was re-extracted with $0.5 \mathrm{ml}$ ethyl acetate then discarded. The organic phases were transferred into the silanized vials and dried under a stream of nitrogen. (Extracts may be stored at $-20^{\circ} \mathrm{C}$ for some days, provided that they are protected from moisture.)

\section{Derivatisation}

To the vial containing the extract, $0.04 \mathrm{ml}$ of a mixture of pyridine/ethylacetate $1: 2000$ and $0.05 \mathrm{ml}$ pentafluoropropionic anhydride was added, the vial was stoppered and the mixture allowed to react at $+25^{\circ} \mathrm{C}$ for one hour. Then, the contents of the vial were dried under a stream of nitrogen. Since the derivate is volatile, the nitrogen-stream must be carefully regulated and stopped immediately after drying. The residue was dissolved in $1 \mathrm{ml}$ ethyl acetate.

\section{Chromatography}

$1 \mu \mathrm{l}$ of the sample was injected twice on a coiled glass column $10 \mathrm{ft} \times 4 \mathrm{~mm}$ internal diameter, packed with $3 \%$ OV-210 on gaschrom Q 80-100 mesh. The injection port temperature was $250^{\circ} \mathrm{C}$, the temperature of oven and detector $170^{\circ}$ and $300^{\circ} \mathrm{C}$, respectively. Gas flow rate (argon-methan 95:5) was $40 \mathrm{ml} / \mathrm{min}$.

\section{Evaluation}

Two methods were used:

a) 5 samples of each urine specimen were hydrolyzed, and in addition to a constant amount of 4-methoxy-3-hydroxyphenylglycol (2000 ng), increasing amounts of 3-methoxy-4-hydroxyphenylglycol were added to 4 of them $(200,400,600,1000 \mathrm{ng})$. From the ratios of peak areas (3-methoxy-4-hydroxyphenylglycol/4-methoxy-3-hydroxyphenylglycol) a regression line was constructed. The intersection with the abscissa gave the amount of 3-methoxy-4-hydroxyphenylglycol in the sample without additional 3-methoxy-4-hydroxyphenylgly col (fig. 1). $\mathrm{r}$ is a measure of the accuracy of the determination. Our values varied from 0.97 to 1.00 .

b) From each urine specimen, only 2 samples were hydrolyzed and only $2000 \mathrm{ng} 4$-methoxy-3-hydroxyphenylglycol added. The resulting peak area ratios correspond to the ratios 3-methoxy=4hydroxyphenylglycol/4-methoxy-3-hydroxyphenylglycol. A calibration curve (established by adding varying amounts of 3-methoxy-4-hydroxyphenylglycol and a constant amount of 4-methoxy-3-hydroxyphenylglycol to Ringer solution and treating it in the same way as an urinary sample) showed that for example $2000 \mathrm{ng} 3$-methoxy-4-hydroxyphenylglycol (corresponding to $2 \mathrm{ng}$ injected) and 2000.ng 4-methoxy-3-hydroxyphenylglycol (corresponding to $2 \mathrm{ng}$ injected) resulted in a ratio of 1.0 (fig. 2).

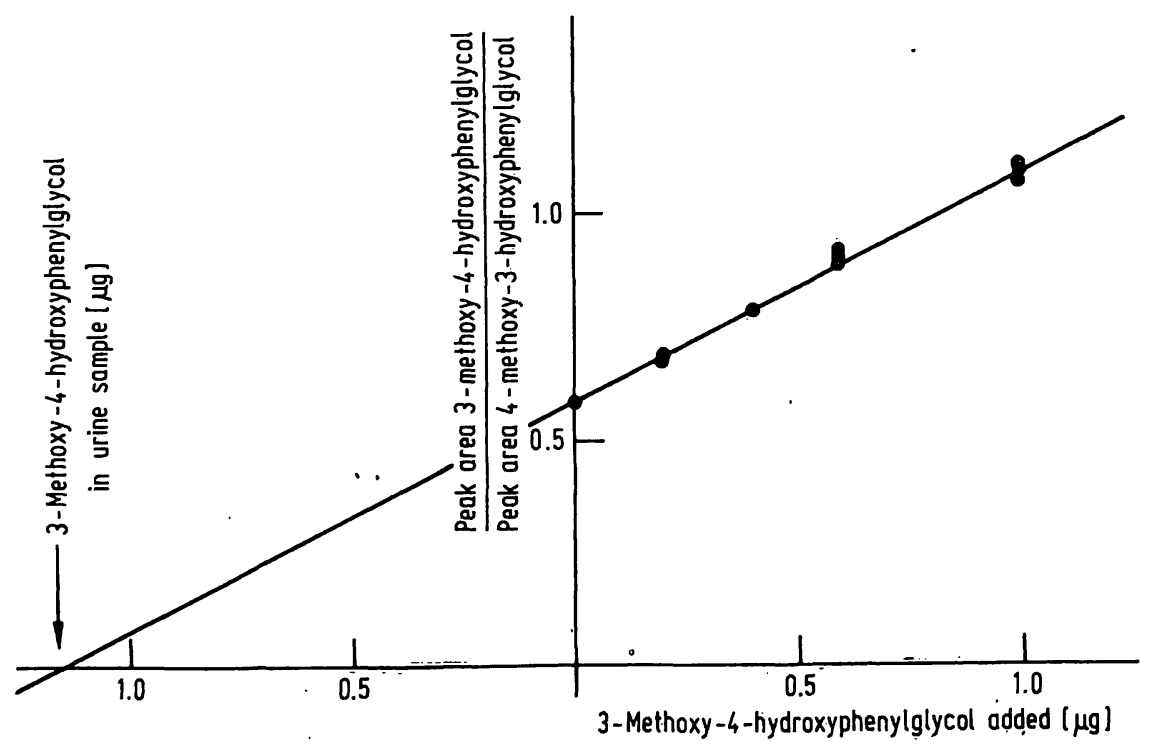

Fig. 1. Regression line for the determination of 3-methoxy-4-hydroxyphenylglycol in a urine sample according to method a). 


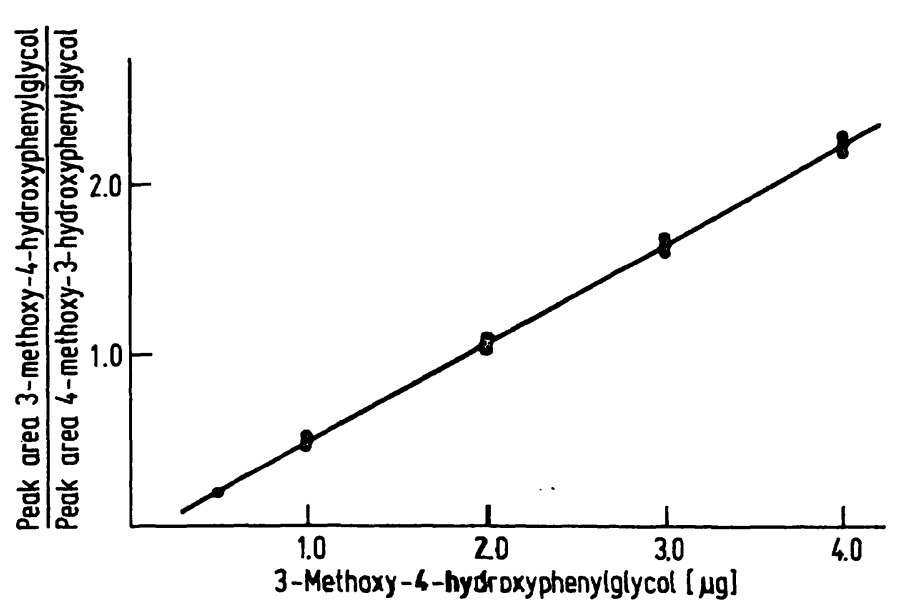

Fig. 2. Calibration curve for the determination of 3-methoxy-4hydroxyphenylglycol, using 4-methoxy-3-hydroxyphenylgly col as internal standard.

With lower amounts of 3-methoxy-4-hydroxyphenylglycol the ratio, counts 3-methoxy-4-hydroxyphenylgly col/counts 4-methoxy-3-hydroxy phenylglycol, tended to be lower than expected; with higher amounts of 3-methoxy-4-hydroxyphenylglycol, it tended to be higher than expected. The deviation was not great, but constant over a series of calibration curves. The reason for this is the loss of a constant amount that is more noticeable in smaller samples. This loss occurred on the column, as could be demonstrated by injection of pure substances. To solve this problem, we always used calibration curves for the calculation.

\section{Results and Discussion}

The conditions for the enzymic hydrolysis are well described by Dekirmenjian \& Maas (1) and only a few parameters were checked by us.

Repeated analysis of the same urine over a period of five months proved that storage is possible without deterioration $\left(\bar{x}=1439 \mu \mathrm{g} / 24 \mathrm{~h}, \mathrm{~s}_{\mathrm{x}}=66, \mathrm{n}=9\right)$ ). The values showed no tendency to decrease.

The extraction with $\mathrm{CHCl}_{3}$ reduced the number of additional peaks. The loss of substance due to $\mathrm{CHCl}_{3}$ extraction was less than $1 \%$. The addition of $\mathrm{NaCl}$ led to a better separation of phases and more efficient extraction. Exact timing during the extraction (vortexing and centrifugation) was necessary for reproducible results. The extraction with $\mathrm{KHCO}_{3}$ resulted in lower recovery, but chromatograms showed fewer interfering peaks and a straight baseline.

The derivatisation reaction according to Fellows et al. (7), Halaris (8) and Sharpless (9), using temperatures between $50-65^{\circ} \mathrm{C}$ led to erratic results in our hands. More reproducible results were obtạined when the reaction was carried out at room temperature, according to Dekirmenjian \& Maas (1). The addition of pyridine further reduced the variability. The loss of the volatile derivate during drying under nitrogen was very difficult to control.
In our opinion, all these problems can.only be solved satisfactorily by using an internal standard the chemical structure of which guarantees a behaviour during the analysis identical to that of the compound to be determined. External standardisation or use of other chemically unrelated compounds as internal standards makes the procedure too susceptible to little variations and precludes routine use.

Besides the OV-210 column, we also used the OV-17 column (Dekirmenjian \& Maas (1)). On this column, a separation of the two isomers was also possible, but in urine extracts the peaks occurred earlier and were located in a region of impurities. Figure 3 shows a chromatogram on the OV-210 column.

For method a), we found a coefficient of variation of $11.3 \%$. Five determinations of the same urine, each containing increased amounts of 3-methoxy-4-hydroxyphenylglycol, resulted in $\bar{x}=2295 \mu \mathrm{g} / 24 \mathrm{~h}, \mathrm{~s}_{\mathrm{x}}=259$. Five single determinations of the same urine according to method b) (only 4-methoxy-3-hydroxyphenylglycol added) resulted in $\bar{x}=2323 \mu \mathrm{g} / 24 \mathrm{~h}, \mathrm{~s}_{\mathrm{x}}=155.10$ determinations in duplicate with another urine, according to method b) resulted in $\bar{x}=1845 \mu \mathrm{g} / 24 \mathrm{~h}, \mathrm{~s}_{\mathrm{x}}=32$, coefficient of variation $1.7 \%$. Both methods gave almost equal results. However, in method $b$ ) the coefficient of variation was somewhat lower. We therefore used method $b$ ) in our subsequent determinations; method a) is not practicable. All determinations were carried out in duplicate with a good correlation between the two assays $(r=0.99$, $\mathrm{n}=197)$.

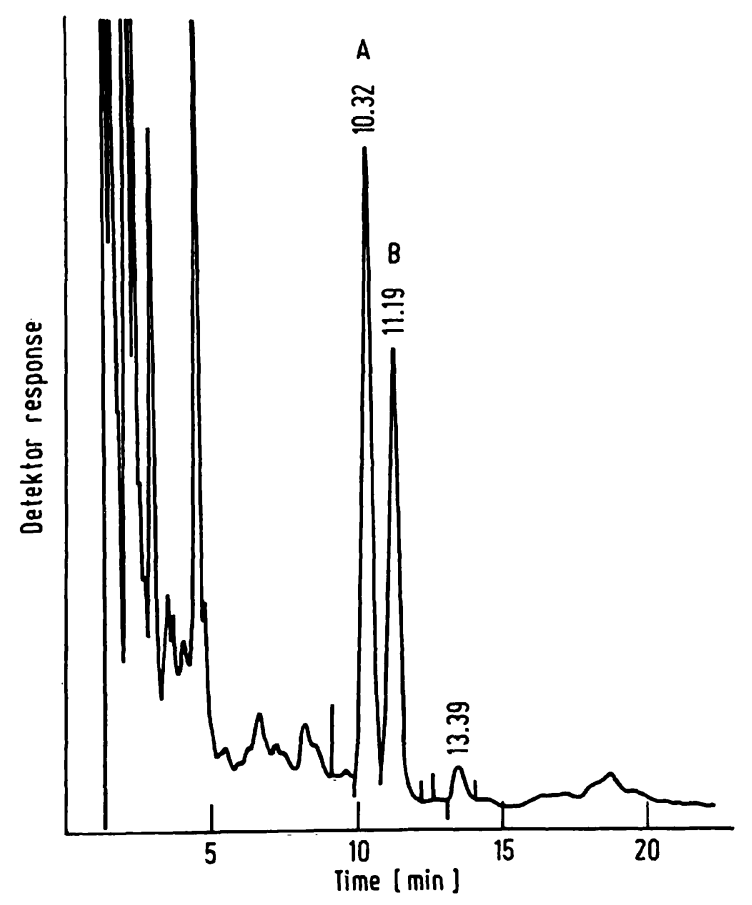

Fig. 3. Typical gas chromatogram of an extract of $0.5 \mathrm{ml}$ urine. According to the calibration curve (Fig. 2), the sample contained $1.83 \mathrm{mg} / 1$ 3-methoxy-4-hydroxyphenylglycol. $A=3-$ methoxy-4-hydroxy phenylglycol $\mathrm{B}=$ 4-methoxy-3-hydroxy phenylglycol. 
Tab. 1. Mean 3-methoxy-4-hydroxyphenylglycol excretion in patients and controls reported in the literature. $\delta=$ male, $q=$ female, $s=$ single episode, $r=$ recurrent, $e=$ endogenous, $n e=$ nonendogenous, values in $\mu \mathrm{g} / 24 \mathrm{~h}$.

Own results: Values are also expressed in $\mu \mathrm{g} / \mathrm{mg}$ creatine (values in brackets). $\mathrm{n}=$ number of individuals. For each individual 2 to 3 separate $24 \mathrm{~h}$ urine samples were analysed in duplicate.

\begin{tabular}{|c|c|c|c|c|c|c|c|}
\hline & Controls & & $\begin{array}{l}\text { Depressed } \\
\text { patients } \\
\text { (mixed group) }\end{array}$ & $\begin{array}{l}\text { Patients with } \\
\text { primary affective } \\
\text { disorder }\end{array}$ & $\begin{array}{l}\text { Unipolar } \\
\text { depressives }\end{array}$ & $\begin{array}{l}\text { Bipolar } \\
\text { depressives }\end{array}$ & $\begin{array}{l}\text { Schizoaffective } \\
\text { patients }\end{array}$ \\
\hline $\begin{array}{l}\text { Karoum et al., } \\
1973(10)\end{array}$ & $1863($ ( ) & $n=9$ & & & & & \\
\hline $\begin{array}{l}\text { Shaw et al., } \\
1973 \text { (11) }\end{array}$ & & & & & 1401 (९) $n=22$ & & \\
\hline $\begin{array}{l}\text { Maas et al., } \\
1974(12)\end{array}$ & $\begin{array}{l}1674(\text { () } \\
1348(\%)\end{array}$ & $\begin{array}{l}\mathrm{n}=19 \\
\mathrm{n}=21\end{array}$ & $\begin{array}{l}1394(\text { () } n=20 \\
1155(\text { (९) } n=48\end{array}$ & & & & \\
\hline $\begin{array}{l}\text { Beckmann } \\
\text { et al., } 1975 \\
\text { (13) }\end{array}$ & & & & & 1860 (९) $n=2$ & $\begin{array}{rll}1590^{\mathrm{II}} & \text { (\%) } \mathrm{n}=3 \\
830^{\mathrm{I}} & \text { (\%) } \mathrm{n}=5\end{array}$ & \\
\hline $\begin{array}{l}\text { Deleon-Jones } \\
\text { et al., } 1975 \\
(14)\end{array}$ & 1348 (\%) & $\mathrm{n}=21$ & 1137 (Q) $\mathrm{n}=33$ & 1032 (\%) $n=21$ & $\begin{array}{ll}1161^{\mathrm{s}} & \text { (\%) } \mathrm{n}=14 \\
1207^{\mathrm{r}} & \text { (\%) } \mathrm{n}=13\end{array}$ & $916 \quad$ (१) $n=5$ & . \\
\hline $\begin{array}{l}\text { Josef et al., } \\
1976 \text { (15) }\end{array}$ & 2740 & $\mathrm{n}=13$ & & & & & \\
\hline $\begin{array}{l}\text { Sharpless, } \\
1977(9)\end{array}$ & $\begin{array}{l}2105(\text { ( ) } \\
1618(\%)\end{array}$ & $\begin{array}{l}\mathrm{n}=6 \\
\mathrm{n}=5\end{array}$ & $\begin{array}{l}\left.2019()^{\circ}\right) \mathrm{n}=10 \\
1357(\text { (१) } \mathrm{n}=10\end{array}$ & & & & \\
\hline $\begin{array}{l}\text { Hollister et al., } \\
1978(16)\end{array}$ & $\begin{array}{l}2254(\delta) \\
1591(९)\end{array}$ & $\begin{array}{l}n=11 \\
n=6\end{array}$ & & & & & \\
\hline $\begin{array}{l}\text { Pickar et al., } \\
1978 \text { (17) }\end{array}$ & 1630 & $n=5$ & & 1184 () $\mathrm{n}=10$ & & & \\
\hline $\begin{array}{l}\text { Schildkraut, } \\
1978(4)\end{array}$ & & & & & $\begin{array}{ll}1950^{\mathrm{e}} & \mathrm{n}=16 \\
1814^{\text {ne }} & \mathrm{n}=13\end{array}$ & $\mathrm{n}=12$ & $1149 n=4$ \\
\hline $\begin{array}{l}\text { Taube et al., } \\
1978 \text { (18) }\end{array}$ & 1029 (\$) & $\mathrm{n}=10$ & & 791 (\$) $n=14$ & $\cdot$ & & \\
\hline $\begin{array}{l}\text { Goodwin \& } \\
\text { Potter, } 1979 \\
\text { (19) }\end{array}$ & 1830 & $\mathrm{n}=18$ & $\mathrm{n}=27$ & $1682 n=23$ & $n=13$ & $\mathrm{n}=10$ & $1520 \mathrm{n}=4$ \\
\hline $\begin{array}{l}\text { Modai et al., } \\
1979(20)\end{array}$ & & & & 1310 (8) $n=13$ & & 1310 (\$) $n=1$ & \\
\hline Own results & $\begin{array}{l}2001(\circlearrowleft) \\
s_{x}=462\end{array}$ & $\mathrm{n}=11$ & & $\begin{array}{l}2009(\delta) n=10 \\
s_{x}=556\end{array}$ & $\begin{array}{l}2166 \quad(\delta) \mathrm{n}=7 \\
\mathrm{~s}_{\mathbf{x}}=542\end{array}$ & $\begin{array}{ll}1339 & n=7 \\
s_{x}=499 & \end{array}$ & \\
\hline \multirow{2}{*}{$\begin{array}{l}(\mu \mathrm{g} / \mathrm{mg} \\
\text { creatinine) }\end{array}$} & $\left(1.19 ; s_{x}=\right.$ & $=0.25)$ & & $\left(1.36 ; s_{\mathbf{x}}=0.50\right)$ & $\left(1.56 ; s_{x}=0.44\right)$ & $\left(1.17 ; s_{\mathbf{x}}=0.39\right)$ & \\
\hline & $\begin{array}{l}1646(\%) \\
\mathrm{s}_{\mathrm{x}}=379\end{array}$ & $\mathrm{n}=9$ & & $\begin{array}{l}1512(\text { ( ) } n=39 \\
s_{x}=526\end{array}$ & $\begin{array}{l}1558(\%) \mathrm{n}=35 \\
\mathrm{~s}_{\mathrm{x}}=521\end{array}$ & & \\
\hline $\begin{array}{l}\text { ( } \mu \mathrm{g} / \mathrm{mg} \\
\text { creatinine) }\end{array}$ & $\left(1.57 ; s_{x}=\right.$ & $=0.46)$ & & $\left(1.41 ; s_{x}=0.45\right)$ & $\left(1.42 ; s_{x}=0.46\right)$ & & \\
\hline
\end{tabular}

The time required for analyzing eight urine specimens was about $48 \mathrm{~h}$ (using the automatic sampler), including incubation.

For validation of our results, we compared them with data found in the literature (see tab. 1). We also found the sex difference in total 3-methoxy-4-hydroxyphenylglycol excretion per $24 \mathrm{~h}$ in patients and controls. In patients, the difference was significant $(p<0.01)$, whereas in controls we only observed a trend $(p<0.1)$. This difference disappears when values are expressed as $\mu \mathrm{g}$ 3-methoxy-4-hydroxyphenylglycol/mg creatinine. 3-methoxy-4-hydroxyphenylglycol excretion in bipolar patients (males and females) was lower $(p<0.05)$ than in unipolar patients, as reported by other authors $(4,13$, $14,19)$. This also applies only for the total 3-methoxy4-hydroxyphenylglycol excretion, but not for 3-methoxy4hydroxyphenylglycol/creatinine.

\section{Acknowledgements}

The authors wish to thank Prof. Dr. Dr. U. Breyer-Pfaff, Institute of Toxicology, Tubingen, for the valuable advice concerning the experiments and for the help in the preparation of the manuscript, and Prof. Dr. H. Remmer for letting us use facilities in his Institute. 


\section{References}

1. Dekirmenjian, H. \& Maas, J. W. (1970), Anal. Biochem. 35, 113-122.

2. Schanberg, S. M., Schildkraut, J. J., Breese, G. R. \& Kopin, I. J. (1968), Biochem. Pharmacol. 17, 247-254.

3. Maas, J. W., Hattox, S. E., Greene, N. M. \& Landis, D. H. (1979), Science 205, 1025-1027.

4. Schildkraut, J. J. (1978), in Psychopharmacology: A Generation of Progress (Lipton, M. A., DiMascio, A. \& Killam, K. F. eds). Raven Press, New York.

5. Goodwin, F. K., Cowdry, R. W. \& Webster, M. H. (1978), in Psychopharmacology: A Generation of Progress (Lipton, M. Y., DiMascio, A. \& Killam, K. F. eds). Raven Press, New York.

6. Feighner, J. P., Robbins, E., Guze, S:B., Woodruff jr., R. A., Winokur, G. \& Murray, R. (1972), Arch. Gen. Psychiatry 26, 57-63.

7. Fellows, L., Riederer, P. \& Sandler, M. (1975), Clin. Chim. Acta 59, 255-257.

8. Halaris, A. E., Dement, E. M. \& Halari, M. E. (1977), Clin. Chim. Acta 78, 285-295.

9. Sharpless, N. S. (1977), Res. Commun. Chem. Pathol. Pharmacol. 18, 257-273.

10. Karoum, F., Lefevre, H., Bigelow, L. B. \& Costa, E. (1973), Clin. Chim. Acta 43, 127-137.
11. Shaw, D. M., O'Keefe, R. \& MacSweeney, D. A. (1973), Psychol. Med. 3, 333-336.

12. Maas, J. W., Dekirmenjian, H. \& Fawcett, J. A. (1974), Int. Pharmacopsychiat. 9, 14-26.

13. Beckmann, H., St.-Laurent, J. \& Goodwin, F. K. (1975), Psychopharmakologia (Berlin) 42, 277-282.

14. Deleon-Jones, F., Maas, J. W., Dekirmenjian, H. \& Sanchez, J. (1975), Am. J. Psychiatry 132, 1141-1148.

15. Joseph, M. H., Baker, H. F., Johnstone, E. C., Crow, T. J. (1976), Psychopharm. 51, 47-51.

16. Hollister, L. E., Davis, K. L., Overall, J. E. \& Anderson, T. (1978), Arch. Gen. Psychiatry 35, 1410-1415.

17. Pickar, D., Sweeney, D. R., Maas, J. W., Heninger, G. R. (1978), Arch. Gen. Psychiatry 35, 1378-1383.

18. Taube, S. L., Kirstein, L. S., Sweeney, D. R., Heninger, G. R. \& Maas, J. W. (1978), Am. J. Psychiatry 135, 78-82.

19. Goodwin, F. K. \& Potter, W. Z. (1979), in Proceedings of the 11th Congress of the Collegium Internationale NeuroPsychopharmacologicum, Vienna 1978 (Saletu, B., Berner, P. \& Hollister, L. eds.), 127-137 Pergamon Press, Oxford.

20. Modai,.I., Apter, A., Golomb, M., Wijsenbeek, H. (1979), Neuropsychobiology $5,181-184$.

Hans Jörg Gaertner Universitäts-Nervenklinik Osianderstraße 22 D-7400 Tübingen 
